Bangladesh J. Pl. Breed. Genet., 30(2): 09-18, 2017

\title{
MORPHOLOGICAL CHARACTERIZATION OF COFFEE (Coffea arabica L.) LANDRACES AT SEEDLING STAGE COLLECTED FROM GUJI ZONES
}

\author{
Itefa Degefa Alemu* and Diriba Shanko Boke
}

\author{
Genetics program, Biology department, Natural and Computational Sciences, Bule Hora \\ University, Ethiopia \\ Corresponding author: ittafaadaggafaa@gmail.com
}

\begin{abstract}
The present study was aimed to determine genetic diversity of Coffea arabica landraces based on morphological characteristics at seedling stage in Guji zones. Three kebeles and twenty-five farmers' coffee landraces were selected based on availability of Coffea arabica landraces from each district by the guidance of Developmental Agency in the kebele. Coffea arabica seeds were collected and planted at kercha nursery sub-site in plastic pots arranged on randomized block design. Seedling characteristics were collected from one year old randomly selected four coffee seedlings from each plot. The results showed that there were significant variations $(\mathrm{p}<0.05)$ between and within Coffea arabica landraces of the district. The seedling height of Coffea arabica collected from Didiba local was highest (11.25) followed by Sorile local (11.17) whereas Ebala local was the least. Coffea arabica from Diqisa local (5.25) was the highest for leaf height followed by Didiba local (5.13), Harobora (5.00) and Wacufora local (5.00). Similarly, Wacufora local (2.05) and Didiba local (2.53) were the highest in leaf width. The Coffea arabica landrace of Qaqali local (6.25) and Harobora local (5.75) were the highest in number of paired leaves. Correlation between the characteristics of coffee seedling showed that seedling height was high and significantly correlated with leaf width $\left(0.62^{* *}\right)$, number of paired leaves $\left(0.58^{* *}\right)$, node number $\left(0.57^{* *}\right)$ and leaf area $(0.64 * *)$. Similarly, leaf height was high and significantly correlated with leaf width $\left(0.72^{* *}\right)$ and leaf area $\left(0.77^{* *}\right)$. Generally, the increase of leaf height increases the leaf width and leaf area. Existence of morphological variation of Coffea arabica at seedling stage was used to determine Coffea arabica diversity in this study area. Therefore, Coffea arabica landraces having high seedling height, leaf height, number of paired leaves and leaf area should get attention during selection for plantation. Additionally, farmers, conservationists and other concerned bodies should take action to conserve and keep the gene pool of these coffees. As a result, it opens the door for biotechnologists to characterize coffee at molecular level and breeder scan take action on it to release superior coffee varieties.
\end{abstract}

Keywords: Coffea arabica; landraces; diversity; morphology; seedling.

\section{INTRODUCTION}

Coffee is one of the most important commercial commodity and foreign currency earnings for 80 developing countries and the current statistics showed that coffee ranked only fifth among internationally traded commodities, after oil, aluminum, wheat and coal (Ponte, 2001). In Ethiopia, coffee plays a significant role in the regional and national economies, and also contributes to the country's foreign currency earning by more than $60 \%$ (Woldetsadik 
and Kebede, 2000). Ninety five percent of coffee production in Ethiopia is produced by smallholder farms found at different levels of domestication and production systems where the intensity and level of management also varies (Grundy, 2005).

The natural genetic diversity or gene pool of economic coffee plants has three distinct categories, namely: a) the primitive cultivars or landraces of traditional agriculture, b) the advanced cultivars produced by plant breeders in the last 100 years, and c) the wild or weedy species related to domesticated cultivars. Ethiopia possesses all three categories of the gene pool for Coffea arabica (Tewolde, 1990). In garden cultivation system, coffee is combined with other crops in open sunlight or under a few shade trees which is commonly referred to as coffee landraces and accounts for 40 to $50 \%$ of national production. In production system, planting material can be landraces but most of the time consists of a limited number of 'improved coffee cultivars' selected by the Jimma Agricultural Research Center (JARC) for their productivity and resistance to diseases (Jean-Pierre and Surendra, 2008). According to the report of these authors, there are factors contributing to the genetic erosion of Ethiopian coffee landraces genetic resources. These factors are Partial reduction of production in some areas for economic, climatic or agronomic reasons, deforestation due to population pressure in the major coffee growing zones and replacement of local landraces by few improved varieties with a narrower genetic base.

Farmers identify their traditional coffee landraces by color of leaves, gross morphology of trees, weight and shape of fruits and beans, presence or absence of aroma during roasting of beans, etc. They give names to the landraces based on the different attributes of the landrace according to the report of Gole et al., (2001). The existence of such a great natural diversity in Ethiopian coffee gene pool is mainly due to maintenance of diverse landraces by local farmers and the presence of wild populations in the forests. Maintenance of diversity on farm is one kind of effective strategy whereby resource-poor farmers practice low-input agriculture in marginal environments to create stable systems (Melaku et al., 2000). Developing genetic diversity requires increasing knowledge of the morphological variability and there is enormous need for phenotype collections. The morphological variation between the collections started to be counted from germination and seedling stage to maturity stage.

In Guji zones of Ethiopia, coffee has a great values and highly be fond of by the community due to its profitable and ceremonial purpose. Most of the districts of Guji zones are occupied by coffees where their landraces diversities maintained by farmers. Coffee population is of traditional cultivated landraces, mostly a mixture of different types (Tadesse, 2015). Characterization of these diversities although accurate at molecular level, most of the time good morphological characteristics containing coffee is preferred by farmers at seedling when plantation takes place on the field. On the nursery site, starting from the stage of germination to early growth stage, morphological characteristics of these coffee seedlings evaluated and plant which is highly interested by farmers are selected and preferably by farmers and prepared for plantation. Taking this in view the study was aimed to assess different morphological characteristics of Coffea arabica landraces and characterization of the diversities of Coffea arabica landraces at seedling stage collected from different districts of Guji zones. 


\section{MATERIALS AND METHODS}

Description of Study Area: The study was conducted on major coffee producing areas of east and west Guji zones, Southern Ethiopia. The survey was carried out at seven districts to collect coffee seeds. They are Bule Hora, Kercha, Odo Shakiso, Uraga, Girja, Adola Rede and Hambala Wamana. The collected landrace coffee seeds were planted in plastic pot at Kercha coffee nursery site.

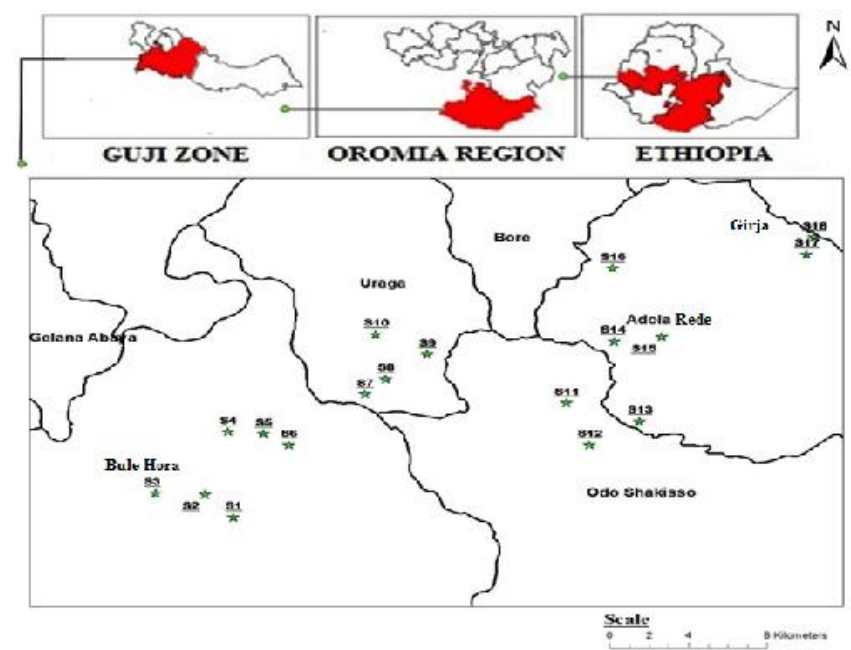

Figure 1. Description of geographical location of coffee seed collection areas

Plant material collection: From Guji zones, seven districts (i.e., Bule Hora, Girja, Hambala Wamana, Adola Rede, Kercha, Uraga and Shakiso) were selected purposively based on the plantation of coffee coverage. From 200 kebeles of these districts, 21 kebeles were selected by simple random sampling (Glass and Hopkins, 1996) where three kebeles were from one district intentionally. Based on the availability of Coffea arabica landraces coverage, representative seeds of Coffea arabica landraces were collected from twenty five house hold farmers' farm land strategically with non-random sampling by the guidance of the kebeles' developmental agency (DA) in order to get specific areas of Coffea arabica landraces. During the collection of these coffee seeds researchers were obtained permission from districts administrative office to keep ethics of the local communities.

Experimental design and planting coffee seeds: After the collection of coffee seeds from representative district, they were received to Kercha nursery sub-site. Fourteen by six meter land was prepared in randomize block design and divided in twenty one plots where three plots were represented three kebeles in the Woreda. Within one plot, five by five arrangements of plastic pots filled with agricultural soil were arranged and three coffee seeds collected from one home garden were planted in one pot. Starting from the plantation day to seedling stage weeding, thinning, shading, guarding, watering or irrigating was done as its requirement.

Collection of seedling parameters: Coffee seedlings characteristics were collected randomly selected coffee from the plot. The seedling characteristics used to assess 
morphological variation of these coffees at seedling stage were seedling height, leaf height, leaf width, number of paired leaves, leaf color, number of nodes, node length, leaf area and leaf shape.

Methods of Data Analysis: Collected seedlings characteristics were analyzed by using Statistical Package soft were SPSS (Version 16) to determine the descriptive statistics like minimum, maximum and mean values of each trait. Additionally Microsoft Excel was used to generate tables and graphs for clear explanation.

\section{RESULTS}

The results revealed that there were significance variations $(\mathrm{P}<0.05)$ in seedling characteristics between and within Coffea arabica landraces collected from seven districts of Guji zones (Table 1). Descriptive analysis of each seedling characteristics has been also assessed that the minimum, maximum and their mean value were presented as shown on the Table 2.

Table1. Analysis of variance between and within Coffea arabica landrace collected from Guji Zones

\begin{tabular}{|c|c|c|c|c|c|c|}
\hline & & $\begin{array}{l}\text { Sum of } \\
\text { Squares }\end{array}$ & DF & $\begin{array}{l}\text { Mean } \\
\text { Square }\end{array}$ & $\mathrm{F}$ & $\begin{array}{l}\text { Significant } \\
\text { level }\end{array}$ \\
\hline \multirow[t]{3}{*}{ SH } & Between Groups & 8.886 & 6 & 1.481 & 0.650 & 0.020 \\
\hline & Within Groups & 25.059 & 11 & 2.278 & & \\
\hline & Total & 33.944 & 17 & & & \\
\hline \multirow[t]{3}{*}{ LH } & Between Groups & 1.302 & 6 & 0.217 & 0.971 & 0.047 \\
\hline & Within Groups & 2.458 & 11 & 0.223 & & \\
\hline & Total & 3.760 & 17 & & & \\
\hline \multirow[t]{3}{*}{ LW } & Between Groups & .349 & 6 & 0.058 & 0.541 & 0.067 \\
\hline & Within Groups & 1.182 & 11 & 0.107 & & \\
\hline & Total & 1.531 & 17 & & & \\
\hline \multirow[t]{3}{*}{ NPL } & Between Groups & 3.573 & 6 & 0.595 & 0.755 & 0.051 \\
\hline & Within Groups & 8.677 & 11 & 0.789 & & \\
\hline & Total & 12.250 & 17 & & & \\
\hline \multirow[t]{3}{*}{ NN } & Between Groups & 5.168 & 6 & 0.861 & 1.281 & 0.341 \\
\hline & Within Groups & 7.399 & 11 & 0.673 & & \\
\hline & Total & 12.567 & 17 & & & \\
\hline \multirow[t]{3}{*}{ NL } & Between Groups & 2.572 & 6 & 0.429 & 0.961 & 0.493 \\
\hline & Within Groups & 4.909 & 11 & 0.446 & & \\
\hline & Total & 7.481 & 17 & & & \\
\hline \multirow[t]{3}{*}{ LA } & Between Groups & 15.848 & 6 & 2.641 & 1.017 & 0.046 \\
\hline & Within Groups & 28.558 & 11 & 2.596 & & \\
\hline & Total & 44.406 & 17 & & & \\
\hline
\end{tabular}

Where: SH=Seedling height, LH=Leaf height, LW=Leaf width, NPL=Number of paired leaf, $\mathrm{NN}=$ Number of nodes, $\mathrm{NL}=$ Node length, $\mathrm{LA}=\mathrm{Leaf}$ area

In this study, as explained on the Fig 2A, there were great variations within Coffea arabica landraces collected from Bule Hora district. Coffea arabica collected from Sorile local was highest in all seedling characteristics whereas Ebala local (6.12) was the least one. This 
shows that there was variation of these coffee landraces within the Bule Hora district. FIG2B also shows that variation within the collection of Coffea arabica landraces in Kercha district. Here, Qoqe local collections showed highest in seedling height (8.50), leaf height (4.75), leaf width (2.00) and leaf area (6.27). However, number of paired leaf (6.25), node number (5.25) and node length (3.77) were highest from Qaqali local Coffea arabica landraces collection.

In Fig 3A Coffea arabica landraces collected from Dari mansa local showed that higher in all seedling characteristics than that of Wacufora local except node length in Hambala Wamana district. However, in Uraga district, Coffea arabica landraces collected from Diqisa local showed higher in seedling height (9.13), leaf height (5.25), leaf width (1.90) and leaf area (6.58) but they show low in number of paired leaf (4.25), node number (3.25) and node length (1.34) Fig 3B. In line with this result the existence of variability among Coffea arabica also confirmed by Ermias (2005) who reported significant differences among coffee germplasm accessions collected from major coffee growing regions of the Ethiopia.

A
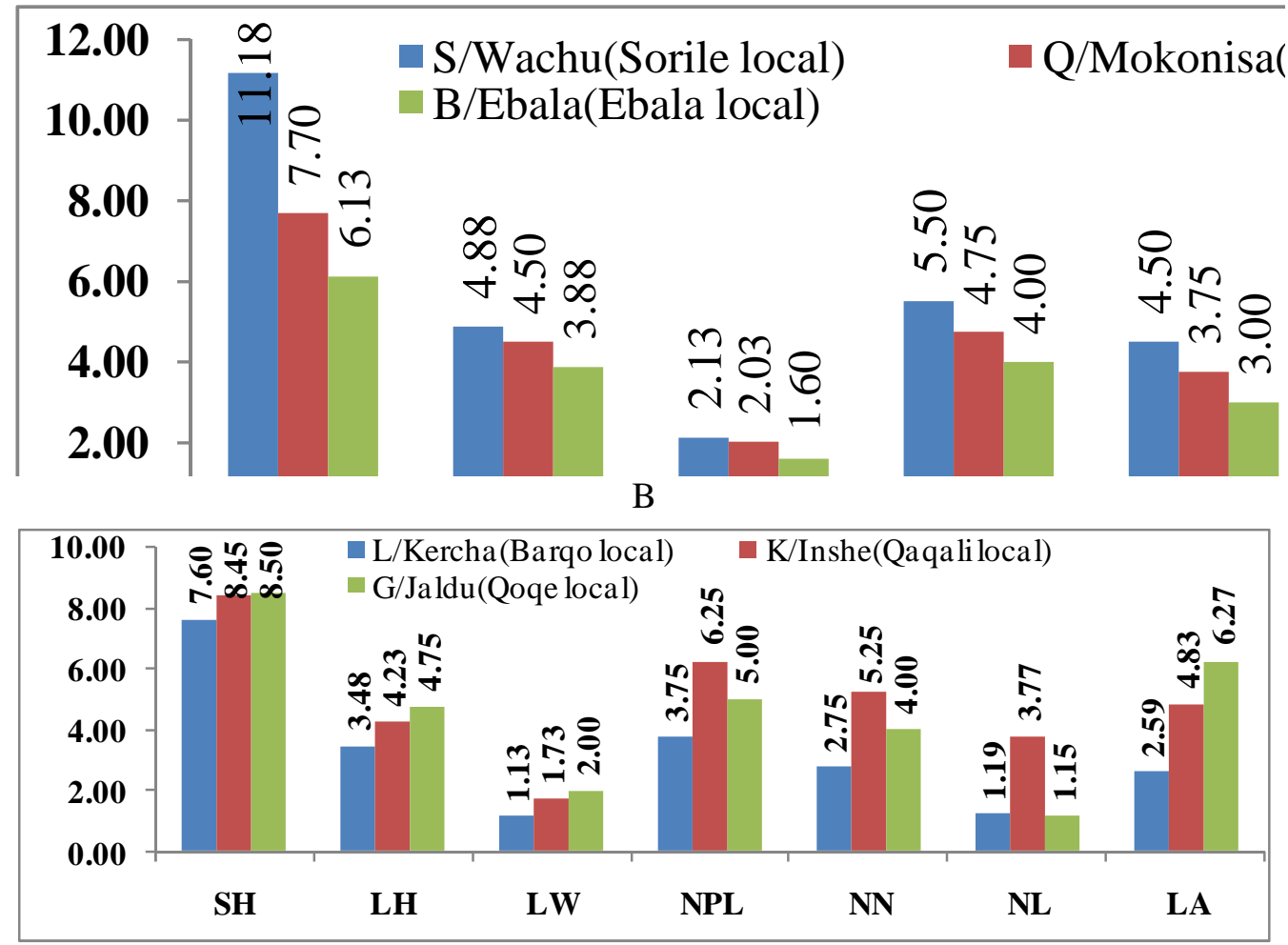

Where, SH=Seedling height, LH=Leaf height, LW=Leaf width, NPL=Number of paired leaf, $\mathrm{NN}=$ Number of nodes, $\mathrm{NL}=$ Node length and $\mathrm{LA}=$ Leaf area

Fig 2A-B. Graphical Representation of Coffea arabicaSeedling Characteristics in Bule Hora (A) and Kercha (B). 
Table 2. Summary of mean, maximum and minimum values of each seedling characteristics of Coffea arabica landraces

\begin{tabular}{cccccc}
\hline Variable & Mean & St/Deviation & Variance & Minimum & Maximum \\
\hline SH & 8.11 & 1.41 & 0.60 & 6.13 & 11.25 \\
LH & 4.54 & 0.47 & 0.09 & 3.48 & 5.25 \\
LW & 1.85 & 0.30 & 0.02 & 1.13 & 2.53 \\
NPL & 4.66 & 0.85 & 0.26 & 3.25 & 6.25 \\
NN & 3.63 & 0.86 & 0.38 & 2.25 & 5.25 \\
NL & 1.29 & 0.66 & 0.16 & 0.88 & 3.77 \\
LA & 5.77 & 1.62 & 0.92 & 2.59 & 9.54 \\
\hline
\end{tabular}

Where, SH=Seedling height, LH=Leaf height, LW=Leaf width, NPL=Number of paired leaves, $\mathrm{NN}=$ Number of nodes, NL=Node length and LA=Leaf area

A
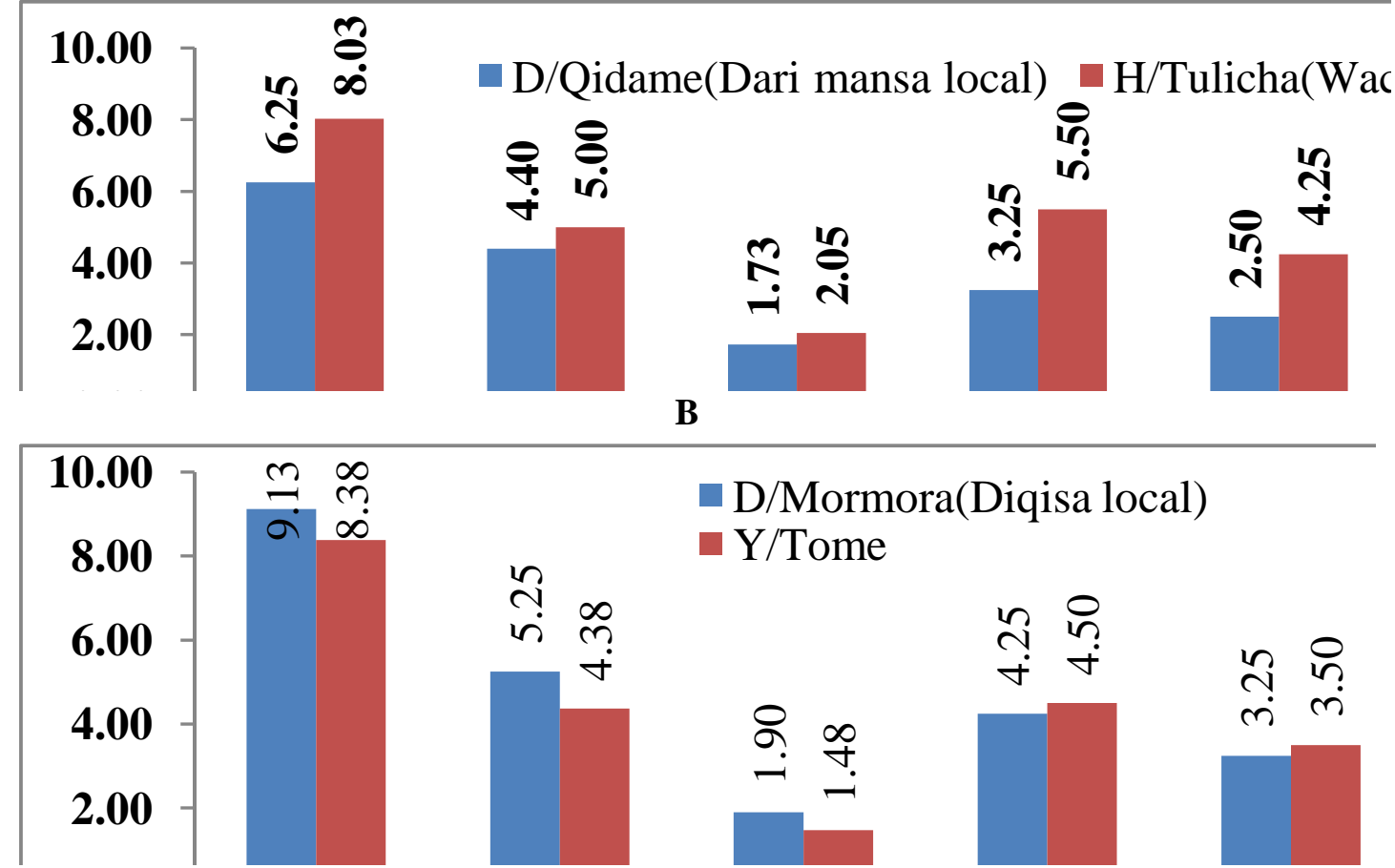

Where, SH=Seedling height, LH=Leaf height, LW=Leaf width, NPL=Number of paired leaves, $\mathrm{NN}=$ Number of nodes, NL=Node length and LA=Leaf area

Figure 3A-B. Graphical representation of Coffea arabica seedling characteristics in Hambala Wamana (A) and Uraga (B).

From Fig 4A, seedling height (7.80), node length (1.12) and leaf area (6.17) were high from Coffea arabica land races collected from Diga local and was less variations were observed in leaf height (4.68), number of paired leaf (5.00) and number of node (4.00) than Coffea arabica landraces collected from Adugnabari local and Harobora local. Similarly, in Girja district, Coffea arabica collected from Ejersanono was lower than that of Dida Guda local in 
all seedling characteristics except leaf height (4.55) and leaf area (5.25) from Fig 4B. From the three kebeles of Adola Rede district Coffea Arabica landraces, Didiba local showed high in all seeding characteristics except it was lower in leaf area (8.56) than that of Xuxe local (9.54) Fig 5. In the present study, Coffea arabica landrace collected from same district were grouped separately and suggesting the existence of high genetic variability. The present study was in line with the report of Melaku (1988) which says the phonotypic variation as well as adaptation under different environmental conditions shows the presence of high Coffea arabica genetic diversity in Ethiopia.

A
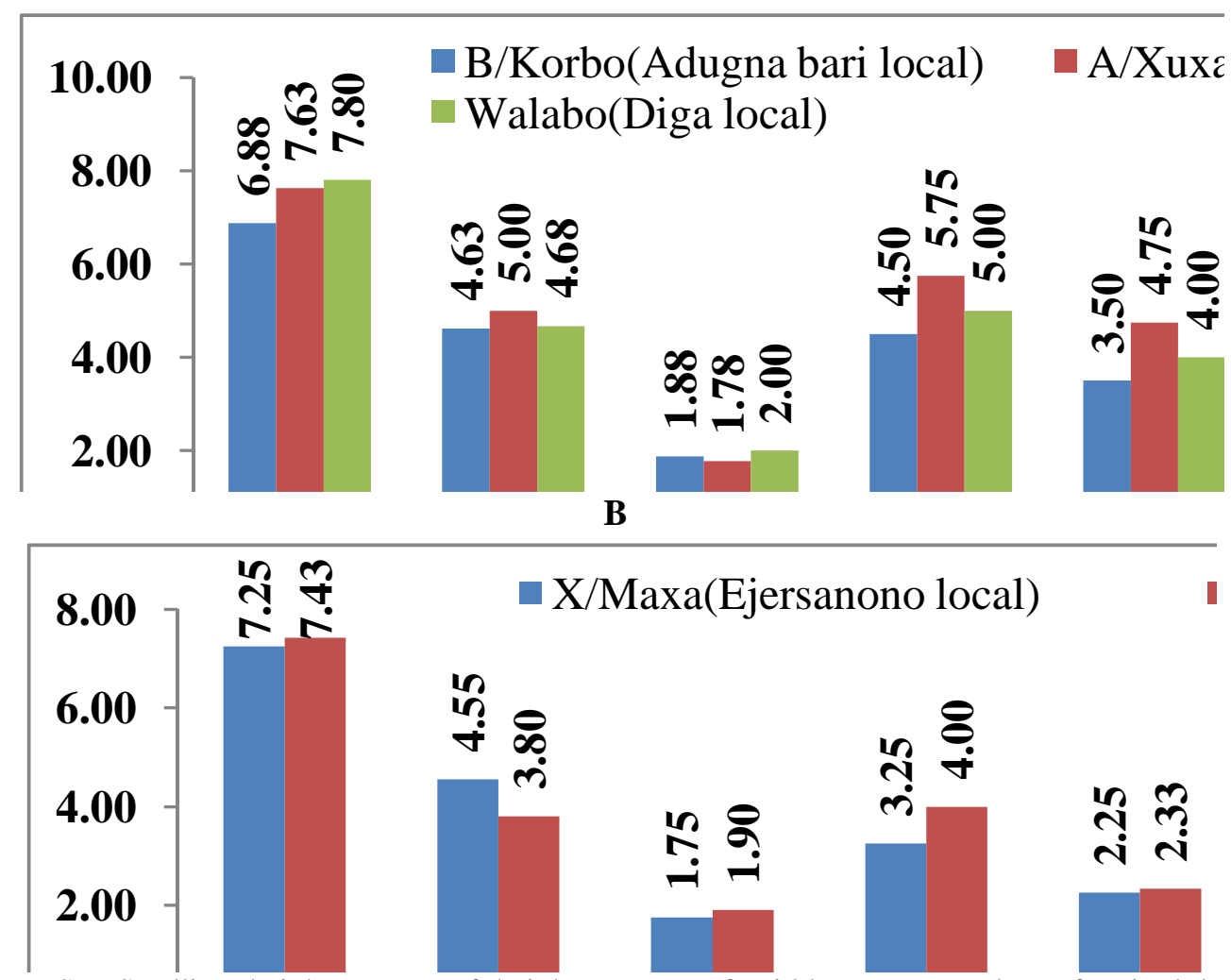

Where, SH=Seedling height, LH=Leaf height, LW=Leaf width, NPL=Number of paired leaves, $\mathrm{NN}=$ Number of nodes, NL=Node length and LA=Leaf area

Figure 4A-B. Graphical representation of Coffea arabica seedling characteristics in Shakiso (A) and Girja (B).

From Table 3, correlation between the Coffea arabica seedling characteristics showed that seedling height was high and significantly correlated with leaf width $\left(0.62^{* *}\right)$, number of paired leaf $(0.58 * *)$, node number $(0.57 * *)$ and leaf area $(0.64 * *)$ which indicates that increasing of seedling height has high contribution for number of leaves and number of nodes. Leaf height was high and significantly correlated with leaf width $\left(0.72^{* *}\right)$ and leaf area $\left(0.77^{* *}\right)$. This shows that as leaf height increases leaf width and leaf area increase together. Leaf width and leaf area were high and significantly $\left(0.85^{* *}\right)$ correlated with each 
other. Number of paired leaf and node number were highly significant $\left(0.98^{* *}\right)$ with each other which highly reflects that the emerging of new leaves produces nodes between the primary paired leaves and the successive emerging leaves. Node length was least and negatively correlated with leaf height $(-0.18)$, leaf width $(-0.10)$ and leaf area $(-0.14)$.

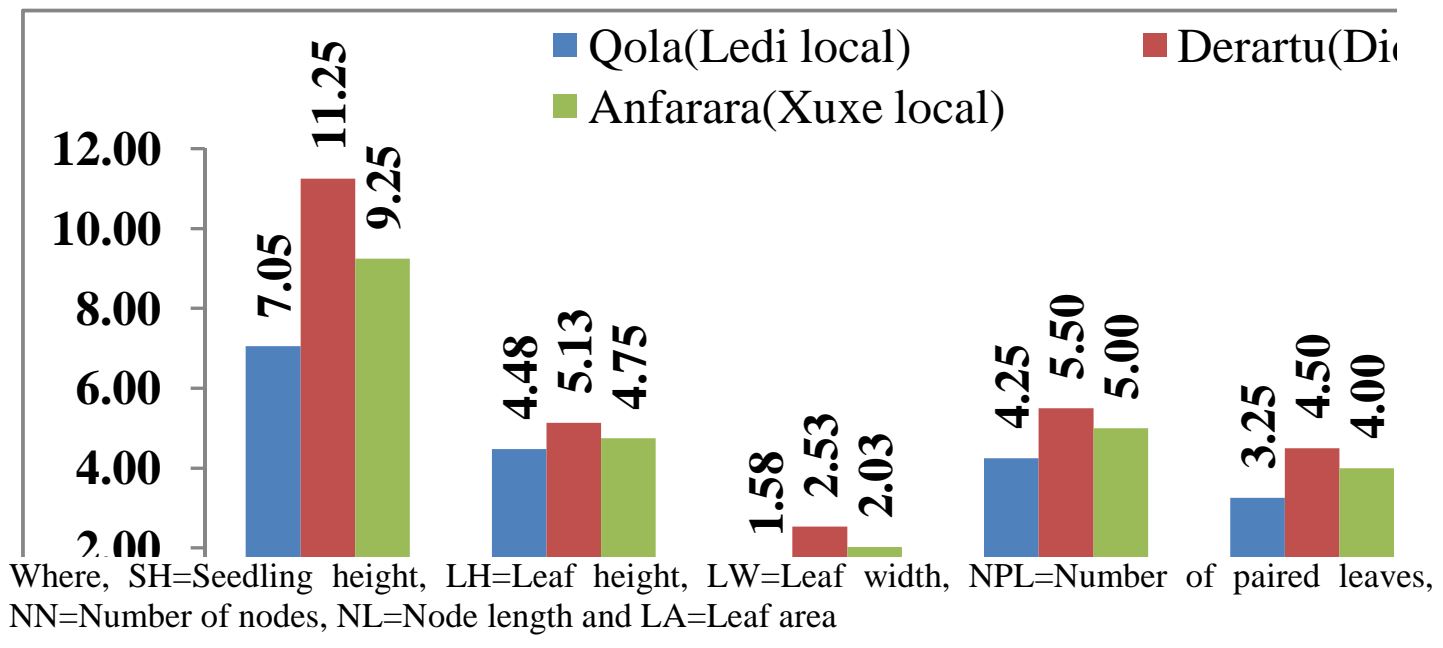

Fig 5. Graphical Representation of Coffea arabicaSeedling Characteristics in Adola Rede.

Table 3. Correlation between seedling characteristics of Coffea Arabica collection from different areas of Guji zones

\begin{tabular}{l|l|l|l|l|l|l|l}
\hline & SH & LH & LW & NPL & NN & NL & LA \\
\hline SH & 1.00 & & & & & & \\
LH & 0.54 & 1.00 & & & & & \\
LW & $0.62^{* *}$ & $0.72^{* *}$ & 1.00 & & & & \\
NPL & $0.58^{* *}$ & 0.47 & 0.49 & 1.00 & & & \\
NN & $0.57^{* *}$ & 0.51 & 0.46 & $0.98^{* *}$ & 1.00 & & \\
NL & 0.20 & -0.18 & -0.10 & 0.43 & 0.43 & 1.00 & \\
LA & $0.64^{* *}$ & $0.77 * *$ & $0.85^{* *}$ & 0.48 & 0.48 & -0.14 & 1.00 \\
\hline
\end{tabular}

Where, SH: Seedling height, LH: Leaf height, LW: Leaf width, NPL: Number of paired leaf, NN: Number of nodes, NL: Node length and LA: Leaf area, $* *$ are significance at 0.05

\section{DISCUSSION}

The development of effective conservation strategies and future plan of coffee is only possible after understanding the extent and the distribution of genetic variation in plant species. The amount of variation can be very different between species and between different populations of a species. This variation in genetic structure of natural populations is one of the central issues in population genetic studies (Kassahun, 2006).The difference in seedling characteristics at similar environment shows that presence of various diverse Coffea arabica in the study area like the report of Olika et al. (2011) who characterized 49 coffee 
germplasm accessions collected from Limu Kossa district for morphological characters and reported the presence of wide genetic variability. These great could be exploited further in order to increase the genetic base of specialty coffee varieties as suggestion of Getachew et al., (2013). An easy technique which used to provide information about selection of one character in progress of another positively characters is correlation analysis. The importance of correlation studies in selection programs is appreciable when highly heritable characters are associated with the important character. So, Coffea arabica landraces having such like characteristics is important for selection in order to improve by breeding program.

\section{CONCLUSION}

Generally, quantitative seedling characteristics like seedling height, leaf height, leaf width, and number of paired leaf, number of nodes, and node length and leaf area as well as qualitative seedling characteristics like leaf surface shape and leaf color of coffee were evaluated on the Kercha nursery sub-site. Analysis of variance at $\mathrm{P}<0.05$ was assessed that there were variations between and within Coffea arabica landraces collected from the districts. In Bule Hora, Sorile local coffee collections were higher than the others in all seedling characteristics. In Hambala Wamana district also, Coffea arabica collected from Dari mansa local were higher than the other locals coffee collections in all characteristics. Similarly, Didiba local coffee collections showed higher seedling characteristics than that of Ledi local and Xuxe local. These great differences between and within coffee seedling characteristics that were collected from different districts shows that their genetic variation which can be evaluated by their morphology at seedling stage.

\section{ACKNOWLADGMENTS}

Bule Hora University and administrative offices of the Guji zones districts are highly acknowledged for their fund and kind support for the completion of this study respectively.

\section{REFERENCES}

Getachew W.M, Sentayehu A, Taye K and Tadesse B (2013). Genetic Diversity Analysis of Some Ethiopian Specialty Coffee (Coffea arabica L.) Germplasm Accessions Based on Morphological Traits.Time Journals of Agriculture and Veterinary Sciences. Vol. 1 (4): 47-54 November, 2013.

Glass, G.V. and Hopkins, K.D. (1996).Statistical Methods in Education and Psychology (third edition). Boston: Allyn\& Bacon.

Gole, Tadesse W, Demel T, Manfred D and Thomas B (2001).Diversity of traditional coffee production systems in Ethiopia and theircontribution to the conservation of coffee genetic diversity.Conference on International Agricultural Research for Development.DeutscherTropentag - Bonn, 9-11 October 2001.

Grundy S (2005). It's not just about the money: An evaluation of the impact of fair trade on improving the livelihoods of smallholder coffee farmers in Oromia Region, Ethiopia. Dissertation submitted in partial fulfillment of the requirements of the Masters of Science degree in poverty reduction and development management of the University of Birmingham.

Jean-Pierre L and Surendra K (2008).Preserving diversity for specialty coffees.A focus on production systems and genetic resources of arabica coffee in Ethiopia.SCAA 20th Annual Conference, Minneapolis, 2-5 May 2008. 
Kassahun T. G (2006). Genetic diversity of wild Coffea arabica populations in Ethiopiaas a contributation to conservation and use planning.Ecology and development series. No 44.https://cuvillier.de/de/shop/publications/2024.

Melaku W (1988). Diversity and the genetic resource base.Ethiopian J. Agaric. Sic. 10:3952.

Melaku W, Tesfaye T, and Refassa F (2000).Keeping diversity alive: an Ethiopian perspective.In Genes in the field: on-farm conservation of crop diversity. Ed. S B Brush.143-161. Lewis Publishers, Boca Raton, USA.

Ponte S (2001). Coffee markets in East Africa: Local responses to global challenges or global responses to local challenges? Working paper sub-series on Globalization and Economic Restructuring in Africa No. XV, CDR working paper 01.5 September 2001.Published and distributed by Centre for Development Research, Copenhagen.

Tadesse W (2015). Environment and Coffee Forest Forum. Coffee: Ethiopia's Gift to the World. The traditional production systems as living examples of crop domestication, and sustainable production and an assessment of different certification schemes. Addis Abeba, Ethiopia.

Tadesse W (2015).Coffee: Ethiopia's Gift to the World: Environment and Coffee Forest Forum. The traditional production systems as living examples of crop domestication, and sustainable production and an assessment of different certification schemes, Environment and Coffee Forest Forum (ECFF).Addis Abeba, Ethiopia 2015.

Tewolde B.G.E (1990). The importance of Ethiopian forests in the conservation of Arabica coffee gene pools.Mitt Inst. Allg. Bot. Hamburg Band 23a, 65-72.

Woldetsadik W and Kebede K (2000).Coffee production systems in Ethiopia. In: Proceedings of the workshop on control of Coffee Berry Disease (CBD) in Ethiopia held in Addis Ababa, Ethiopian Agricultural Research Institute, Addis Ababa, 13-15 August 1999: 99-106. 